\title{
Pengaruh Penerapan Prinsip Good Corporate Governance Terhadap Kinerja Non Keuangan Pada Perum Bulog Sub Divre Semarang
}

\author{
Adela Rahma Putri' ${ }^{1}$, Sartika Wulandari² \\ ${ }^{1}$ Jurusan Akuntansi, Universitas Stikubank Semarang \\ Email: adelarahma755@gmail.com \\ ${ }^{2} J u r u s a n$ Akuntansi, Universitas Stikubank Semarang \\ Email: sartikawulan@edu.unisbank.ac.id
}

\begin{abstract}
Non-financial performance is a performance that shows the growth of a company. Companies can find out the level of success of their companies by using non-financial performance analysis. The purpose of this study is to test whether there is an influence between transparancy, accountability, responsibility, independency and fairness on the company's non-financial performance. The method used is nonprobability sampling with purposive sampling method and obtained through a questionnaire with a total of 40 respondents. Based on the results of hypothesis testing, it shows that the principles of transparancy and accountability have no significant effect on non-financial performance, while the principles of responsibility, independency and fairness have a positive and significant impact on non-financial performance.
\end{abstract}

Keywords: Non-financial performance, Transparancy, Accountability, Responsibility, Independency, Fairness

\begin{abstract}
ABSTRAK
Kinerja non keuangan adalah kinerja yang menunjukan pertumbuhan suatu perusahaan. Perusahaan dapat mengetahui tingkat keberhasilan perusahaannya dengan menggunakan analisis kinerja non keuangan. Tujuan dari penelitian ini yaitu untuk menguji apakah terdapat pengaruh antara transparancy, accountability, responsibility, independency dan fairness terhadap kinerja non keuangan perusahaan. Metode yang digunakan yaitu non-probability sampling dengan metode purposive sampling dan didapatkan melalui kuesioner dengan jumlah responden sebanyak 40. Berdasarkan hasil uji hipotesis menunjukan prinsip transparancy dan accountability tidak berpengaruh signifikan terhadap kinerja non keuangan, sedangkan prinsip responsibility, independency dan fairness berpengaruh positif dan signifikan terhadap kinerja non keuangan.
\end{abstract}

Kata Kunci: Kinerja non keuangan, Transparancy, Accountability, Responsibility, Independency, Fairness

\section{Pendahuluan}

Kinerja dapat diartikan sebagai hasil kerja secara kualitas dan kuantitas yang dicapai oleh seseorang atau organisasi dalam melaksanakan tugasnya sesuai dengan tanggung jawab yang diberikan[1]. Sedangkan menurut Dessler, kinerja adalah perbandingan antara hasil kerja yang nyata dengan standar atau kerja yang ditetapkan[2]. Kinerja perusahaan merupakan salah satu bentuk atau tolak ukur keberhasilan atas pelaksanaan fungsi-fungsi dalam perusahaan. Setiap bagian dari 
perusahaan tersebut merupakan fungsi yang menjadi pelaksana dari aktivitas perusahaan.

Kinerja non keuangan adalah kinerja yang menunjukan pertumbuhan suatu perusahaan. Perusahaan dapat mengetahui tingkat keberhasilan perusahaannya dengan menggunakan analisis kinerja non keuangan. Analisis kinerja non keuangan merupakan salah satu faktor pendukung dalam perusahaan, karena dari analisis tersebut kita dapat menilai keberhasilan perusahaan tersebut. Dalam analisis kinerja non keuangan kita dapat melihat kualitas, kepuasan, serta kinerja dari suatu perusahaan[3].

Sistem pengukuran kinerja perusahaan yang hanya mengandalkan perspektif keuangan terkadang banyak memiliki kelemahan dan keterbatasan. Perspektif non keuangan dianggap sebagai bagian yang bila ikut diperhatikan, pada akhirnya dapat mendongkrak kinerja keuangan yang merupakan keinginan utama dari pemegang saham karena informasi non finansial dapat menambah keyakinan terhadap kualitas proses pengendalian manajemen. Oleh karena itu, perusahaan sebaiknya menerapkan suatu konsep penilaian kinerja yang tidak hanya dilihat dari sisi keuangan namun juga dilihat dari sisi non keuangan, untuk itu perusahaan dapat menggunakan metode Balance Scorecard (BSC). [4]

Balanced Scorecard (BSC) yang diperkenalkan pertama kali oleh Kaplan dan Norton adalah suatu perangkat pengukuran kinerja yang memberikan manajemen puncak suatu pandangan yang cepat dan komprehensif tentang perusahaan. Balanced scorecard adalah suatu teknik yang banyak digunakan untuk mengukur kinerja perusahaan[5]. Balanced scorecard mengukur kinerja perusahaan pada empat perspektif yang seimbang (balanced), yaitu finansial, pelanggan, proses bisnis internal, dan proses pembelajaran dan pertumbuhan[6].

Salah satu kriteria penilaian kinerja dapat dilihat dari penerapan corporate governance di dalamnya. Menurut Forum for Corporate Governance in Indonesia (FCGI), praktek bisnis yang menerapkan corporate governance yang baik atau Good Corporate Governance (GCG) juga akan berdampak positif untuk meningkatkan kinerja perusahaan melalui terciptanya proses pengambilan keputusan yang lebih baik, meningkatkan efisiensi perusahaan, serta lebih meningkatkan pelayanan kepada stakeholders.

GCG berpengaruh pada peningkatan nilai perusahaan karena dapat meningkatkan profit melalui operasional yang lebih efesien. GCG merupakan gabungan prinsip-prinsip dasar dalam membangun suatu tatanan etika kerja dan kerjasama agar tercapai rasa kebersamaan, keadilan, optimasi dan harmonisasi hubungan sehingga dapat menuju kepada tingkat perkembangan yang penuh dalam suatu organisasi atau badan usaha[7]. Corporate governance sendiri merupakan sebuah konsep yang diajukan demi peningkatan kinerja perusahaan melalui supervisi atau monitoring kinerja manajemen dan menjamin akuntabilitas manajemen terhadap stakeholder dengan mendasarkan pada kerangka peraturan[8].

Transparansi (Transparancy) adalah memberikan informasi secara terbuka dan jujur kepada stakeholders berdasarkan pertimbangan, keterbukaan dalam 
pengungkapan informasi mengenai perusahaan akan meningkatkan kepercayaan stakeholders terhadap perusahaan[9]. Adanya hubungan antara transparansi dan kinerja non keuangan perusahaan yaitu perusahaan harus menyediakan informasi yang lebih tepat waktu dan transparansi dalam mengemukakan informasi yang relevan mengenai perusahaan[10].

$\mathrm{H}_{1}$ : Transparancy berpengaruh positif terhadap kinerja non keuangan perusahaan.

Akuntabilitas (Accountability) adalah pertanggungjawaban perusahaan atas kinerja secara transparan dan wajar kepada stakeholders. Untuk itu, perusahaan harus dapat mempertanggungjawabkan kinerjanya secara transparan dan wajar. Perusahaan harus dikelola secara benar, terukur dan sesuai dengan kepentingan perusahaan dengan tetap memperhitungkan kepentingan pemegang saham dan pemangku kepentingan lain. Semakin jelas wewenang dan fungsi pelaksanaan serta pertanggungjawaban struktur organisasi dalam perusahaan maka pengelolaan perusahaan akan terlaksana secara efektif dan meningkatkan kepercayaan prinsipal sehingga akan meningkatkan kinerja perusahaan[9].

$\mathrm{H}_{2}$ : Accountability berpengaruh positif terhadap kinerja non keuangan perusahaan.

Responsibilitas (Responsibility) adalah sikap perusahaan dalam mengelola usahanya berdasarkan peraturan perundang-undangan yang berlaku[9]. Perusahaan harus mematuhi peraturan perundang-undangan serta melaksanakan tanggungjawab kepada masyarakat dan lingkungan sehingga dapat terpelihara kesinambungan usaha dalam jangka panjang dan mendapat pengakuan sebagai good corporate governance[11].

$\mathrm{H}_{3}$ : Responsibility berpengaruh positif terhadap kinerja non keuangan perusahaan.

Independensi (Independency) adalah sikap perusahaan dalam mengambil keputusan tanpa terikat dengan pihak manapun atau pihak yang mendominasi. Dengan tidak adanya benturan kepentingan dalam pengelolaan perusahaan dapat berdampak pada meningkatnya kepercayaan prinsipal dan memastikan bahwa perusahaan telah bersikap objektif dalam pengelolaannya[9]. Untuk melancarkan pelaksanaan asas GCG, perusahaan harus dikelola secara independen sehingga masingmasing organ perusahaan tidak saling mendominasi dan tidak dapat diintervensi oleh pihak lain[7].

$\mathrm{H}_{4}$ : Independency berpengaruh positif terhadap kinerja non keuangan perusahaan.

Kewajaran (Fairness) adalah keadilan dan kesetaraan perusahaan dalam memenuhi kepentingan stakeholders yang timbul berdasarkan perjanjian dan peraturan perundang-undangan yang berlaku[9]. Dalam melaksanakan kegiatannya, perusahaan harus senantiasa memperhatikan kepentingan pemegang saham dan pemangku kepentingan lainnya berdasarkan asas kewajaran dan kesetaraan[7]. Perusahaan harus senantiasa memperlihatkan kepentingan pemegang saham dan pemangku kepentingan lainnya yang berdasarkan asas kesetaraan dan kewajaran. Perusahaan harus memberikan kesempatan kepada pemangku kepentingan untuk memberikan masukkan dan menyampaikan pendapat bagi kepentingan perusahaan.

H5: Fairness berpengaruh positif terhadap kinerja non keuangan perusahaan. 
Salah satu fenomena yang terkait terjadi pada PT. Jansen Indonesia yang merupakan perusahaan/perseroan yang menjalankan usaha di bidang furniture dan memasarkan hasil produksinya baik ke pasaran ekspor maupun pasar domestik. PT. Jansen Indonesia membukukan laba menurun dari Rp.208.455.724.471 pada tahun 2007 kemudian mengalami penurunan menjadi Rp. 123.728.723.326 pada tahun 2008 dan mengalami kerugian sebesar Rp 122.904.267.009 pada tahun 2009. Penurunan laba ini terjadi akibat penurunan penjualan dari Rp. 2.800.084.343.000 pada tahun 2007 menjadi Rp. 1.196.932.130.000 pada tahun 2008 namun demikian naik menjadi Rp. 1.741.760.687.000 pada tahun 2009. Selama ini PT. Jansen menggunakan sistem pengukuran kinerja dengan metode scorecard dan hanya menggunakan profitabilitas sebagai indikator kinerja, sehingga sulit bagi perusahaan untuk mengidentifikasi penyebab atau masalah-masalah terjadinya penurunan kinerja dari perspektif non keuangan[12].

Beberapa penelitian menguji penerapan prinsip GCG terhadap kinerja. Hasil penelitian yang dilakukan oleh beberapa peneliti sebelumnya mengungkapkan bahwa penerapan prinsip GCG yang meliputi (transparency, accountability, independency, responsibility, fairness) memiliki pengaruh positif dan signifikan terhadap kinerja[10], [11], [13], [9]. Namun berbeda dengan penelitian lain yang menyatakan bahwa penerapan prinsip GCG berpengaruh tapi tidak signifikan terhadap kinerja[14]. Penerapan prinsip good corporate governance secara teoritis dapat meningkatkan kinerja perusahaan, mengurangi resiko yang mungkin dilakukan oleh dewan yang menguntungkan diri sendiri dan umumnya good corporate governance dapat meningkatkan kepercayaan investor untuk menanamkan modalnya yang berdampak terhadap kinerjanya.

BSC merupakan alat pendukung yang digunakan untuk komunikasi, motivasi, dan mengevaluasi strategi organisasi utama[15]. BSC bukan merupakan perspektif tunggal namun saling berkaitan satu dengan yang lainnya sehingga akan tercapai sebuah penerapan konsep BSC yang efektif pada suatu perusahaan. Salah satu kunci keberhasilan penerapan BSC adalah adanya dukungan penuh dari setiap lapisan manajemen yang ada dalam organisasi. BSC tidak hanya berfungsi sebagai laporan, tetapi lebih dari itu, BSC haruslah benar-benar merupakan refleksi dari sebuah strategi perusahaan serta visi organisasi. Bahkan BSC dapat dipandang sebagai sebuah alat untuk mengkomunikasikan strategi dan visi organisasi perusahaan secara kontinyu.[16]

Beberapa penelitian menguji penerapan prinsip GCG yang meliputi (transparency, accountability, independency, responsibility, fairness) terhadap kinerja berbasis Balance Scorecard. Hasil penelitian yang dilakukan oleh peneliti sebelumnya menyatakan bahwa prinsip GCG berpengaruh signifikan terhadap kinerja berbasis BSC[17]. Pratiwi dan Putri menyatakan prinsip GCG berpengaruh terhadap kinerja berbasis BSC[18]. Puspitha dan Sujana menyatakan prinsip GCG berpengaruh positif terhadap kinerja berbasis BSC[19]. Kesuma dan Nurhayati menyatakan bahwa prinsip GCG berpengaruh positif signifikan terhadap kinerja berbasis BSC[20]. Penerapan prinsip GCG dapat mendorong kinerja, karena dapat memberikan arahan yang baik dalam mengelola perusahaan dan menjamin tindakan manajemen, sehingga efektivitas dan efisiensi pengelolaan perusahaan dapat tercapai serta menciptakan perlindungan 
terhadap seluruh kepentingan stakeholder. Pengelolaan perusahaan yang baik akan menumbuhkan kepercayaan masyarakat pada perusahaan.

Penilaian kinerja perusahaan tidak hanya dilihat dari sisi keuangan namun juga dilihat dari sisi non keuangan. Ukuran kinerja non keuangan merupakan respons terhadap masalah-masalah perusahaan. Kelima prinsip GCG kemudian menjadi strategi perancangan yang menjadi konsep unggul untuk membentuk kinerja yang baik. Beberapa kinerja yang diukur dalam sistem non keuangan adalah kinerja kehadiran pegawai, prestasi kerja, kualitas produk, perkembangan perusahaan, dan lingkungan kerja[3].

Beberapa penelitian menguji penerapan prinsip GCG yang meliputi (transparency, accountability, independency, responsibility, fairness) terhadap kinerja non keuangan perusahaan. Hasil penelitian yang dilakukan oleh peneliti sebelumnya menyatakan bahwa secara simultan penerapan prinsip GCG berpengaruh signifikan terhadap kinerja non keuangan[21]. Namun berbeda dengan hasil penelitian lainnya menyatakan bahwa penerapan prinsip GCG secara bersama-sama tidak berpengaruh terhadap kinerja non keuangan[22]. Perusahaan yang menerapkan sistem GCG yang baik akan mampu menciptakan hubungan profesional yang kuat baik antar anggota perusahaan. Hal ini sangat penting dikarenakan kerjasama antar individu yang berada dalam perusahaan merupakan fondasi untuk berkembang dan memberikan kontribusi baik secara internal maupun eksternal serta dapat mencapai tujuan.

Salah satu perusahaan yang menerapkan praktek GCG adalah Perusahaan Umum Badan Urusan Logistik atau yang disingkat dengan Perum BULOG. Pada website resmi BULOG, dijelaskan bahwa BULOG merupakan Perusahaan Umum milik negara dan merupakan sebuah lembaga pangan di Indonesia yang mengurusi tata niaga beras dengan ruang lingkup bisnis yang meliputi usaha logistik atau pergudangan, melakukan perdagangan komoditi pangan dan usaha eceran[23]. Operasional barang dan jasa harus dilaksanakan berdasarkan prinsip-prinsip yang transparan, akuntabel, bertanggung jawab, mandiri dan penuh keadilan untuk meningkatkan kepercayaan masyarakat. Pengoptimalan elemen-elemen ini menjadi sorotan dan tumpuan bagi setiap perusahaan agar dapat bertahan di era globalisasi saat ini. Penerapan GCG serta prinsip-prinsipnya baik dalam manajemen maupun pengelolaan bisnis usaha akan memacu operasional bisnis perusahaan ini menjadi efektif dan bernilai lebih baik.

Sejalan dengan tuntutan untuk terus meningkatkan kualitas pelayanan publik, maka Perum Bulog Sub Divre Semarang perlu melakukan pengukuran kinerja seluruh aspek dalam lingkup organisasinya yang saling berhubungan dalam mewujudkan visi misi perusahaan sesuai dengan ketetapan GCG yang telah ada. Penerapan GCG di perusahaan dipandang perlu diteliti untuk melihat kinerja non-keuangan dengan prinsip transparency, accountability, responsibility, independency, fairness pada perusahaan BULOG, karena tujuan utama perum BULOG adalah memberikan layanan pangan untuk masyarakat dan diharapkan perum BULOG melakukan pengukuran kinerja non finansial untuk mewujudkan visi misi perusahaan. Pengukuran yang menyeluruh inilah yang akan menghasilkan keseimbangan kinerja antara aspek finansial dan non finansial yang akan membuat perum BULOG dapat terus memenuhi 
kebutuhan pangan dengan kualitas pelayanan yang baik dan juga dapat memupuk profit sebagai hasil akhir.

\section{Metode Penelitian}

\section{Populasi dan Sampel}

Populasi dalam penelitian ini adalah Perusahaan Umum BULOG Sub Divre 1 Semarang yang berlokasi di Jl. Siliwangi No.289, Kalibanteng Kulon, Kecamatan Semarang Barat, Kota Semarang, Jawa Tengah, Kode pos 50145. Sampel yang akan digunakan pada penelitian ini untuk menilai kinerja balance scorecard dari perspektif pembelajaran dan pertumbuhan, peneliti mengambil sampel seluruh populasi karyawan Perum Bulog. Kemudian untuk menilai kinerja balance scorecard dari perspektif pelanggan, peneliti mengambil sebagian pengunjung/pelanggan. Dan total sampel yang digunakan untuk penelitian ini sebanyak 40 responden. Pengambilan sampel dilakukan menggunakan teknik non-probability sampling dengan metode purposive sampling. Purposive sampling merupakan teknik pengambilan sampel dengan menentukan kriteria-kriteria tertentu[24]. Sementara kriteria yang digunakan adalah kriteria inklusi dimana subjek penelitian dapat mewakili sampel yaitu responden yang merupakan karyawan Perusahaan Umum BULOG Sub Divre 1 Semarang mulai dari staff kantor cabang, keuangan, accounting, komersial, staff pengadaan barang hingga staff operasional pergudangan dan sebagian pelanggan (customers). Untuk perspektif pelanggan yaitu konsumen yang datang dan menggunakan produk yang dipasarkan oleh Bulog.

\section{Jenis dan Sumber Data}

Jenis data yang digunakan dalam penelitian ini merupakan data primer dengan menyebarkan kuesioner yang kemudian akan diisi oleh responden yang diperoleh langsung dari objek penelitian dengan menggunakan alat pengukuran atau alat pengambilan data langsung pada objek sebagai sumber informasi yang dicari.

Sumber data primer yang diambil dalam penelitian ini didapat secara langsung dari struktural perusahaan umum BULOG Sub Divre 1 Semarang beserta pelanggan (customers) untuk mendapatkan informasi mengenai penelitian.

\section{Teknik Analisis Data}

Pengujian hipotesis penelitian dilakukan dengan menggunakan pendekatan Structural Equation Model (SEM) berbasis Partial Least Square (PLS). PLS adalah model persamaan struktural (SEM) yang berbasis komponen atau varian. Structural Equation Model (SEM) adalah salah satu bidang kajian statistik yang dapat menguji sebuah rangkaian hubungan yang relatif sulit terukur secara bersamaan.

Teknik analisis dalam penelitian ini menggunakan teknik PLS yang dilakukan dengan dua tahap, yaitu: 
1. Tahap pertama adalah melakukan uji measurement model, yaitu menguji validitas dan reliabilitas konstruk dari masing-masing indikator.

2. Tahap kedua adalah melakukan uji structural model yang bertujuan untuk mengetahui ada tidaknya pengaruh antar variabel/korelasi antara konstruk konstruk yang diukur dengan menggunakan uji t dari PLS itu sendiri.

\section{Hasil Dan Pembahasan \\ Uji Validitas}

Untuk mengevaluasi validitas diskriminan dapat dilihat dengan metode average variance extracted (AVE) untuk setiap konstruk atau variabel laten. Dan nilai AVE yang diharapkan melebihi dari angka > 0,5.

Tabel 1. AVE

\begin{tabular}{|c|c|c|c|c|}
\hline & $\begin{array}{l}\text { Cronbach's } \\
\text { Alpha }\end{array}$ & rho_A & $\begin{array}{l}\text { Composite } \\
\text { Reliability }\end{array}$ & $\begin{array}{l}\text { Average } \\
\text { Variance } \\
\text { Extracted (AVE) }\end{array}$ \\
\hline Accountability (X2) & 0.868 & 0.871 & 0.910 & 0.717 \\
\hline Fairness (X5) & 0.804 & 0.807 & 0.872 & 0.630 \\
\hline Independency (X4) & 0.792 & 0.792 & 0.865 & 0.616 \\
\hline Kinerja Non-Keuangan (Y) & 0.882 & 0.885 & 0.908 & 0.585 \\
\hline Responsibility (X3) & 0.838 & 0.852 & 0.892 & 0.674 \\
\hline Transparancy (X1) & 0.820 & 0.826 & 0.874 & 0.581 \\
\hline
\end{tabular}

Sumber: Olah Data PLS

Pada tabel 1. diketahui nilai AVE untuk variabel transparancy sebesar 0,581, variabel accountability sebesar 0,717, variabel responsibility sebesar 0,674, variabel independency sebesar 0,616, variabel fairness sebesar 0,630 dan variabel kinerja non keuangan sebesar 0,585. Dari tabel 1. dapat diketahui bahwa nilai AVE masing-masing konstruk sudah berada diatas 0,5. Oleh karena itu semua variabel dikatakan valid karena memiliki nilai AVE diatas 0,5. Menurut Chin yang dikutip oleh Imam Ghozali, nilai AVE antara 0,5-0,6 sudah dianggap cukup. 


\section{Uji Hipotesis}

Pada penelitian ini dilakukan hasil uji hipotesis dengan hasil sebagai berikut:

Tabel 2. Uji Hipotesis

\begin{tabular}{|c|c|c|c|c|c|c|c|}
\hline & $\begin{array}{l}\text { Origina } \\
\text { I } \\
\text { Sampl } \\
\text { e (0) }\end{array}$ & $\begin{array}{l}\text { Samp } \\
\text { le } \\
\text { Mean } \\
\text { (M) }\end{array}$ & $\begin{array}{l}\text { Standa } \\
\text { rd } \\
\text { Deviati } \\
\text { on } \\
\text { (STDE } \\
\text { V) }\end{array}$ & $\begin{array}{l}\text { T } \\
\text { Statisti } \\
\text { cS } \\
(\mid \text { O/ST } \\
\text { DEV|) }\end{array}$ & $\begin{array}{l}\mathbf{P} \\
\text { Value } \\
\text { s }\end{array}$ & $\begin{array}{l}R \\
\text { Squar } \\
\mathrm{e}\end{array}$ & $\begin{array}{l}\text { Q } \\
\text { Squar } \\
\text { e }\end{array}$ \\
\hline $\begin{array}{l}\text { Accountability (X2) -> Kinerja Non- } \\
\text { Keuangan (Y) }\end{array}$ & 0.012 & 0.013 & 0.107 & 0.109 & 0.913 & & \\
\hline $\begin{array}{l}\text { Fairness (X5) -> Kinerja Non-Keuangan } \\
(Y)\end{array}$ & 0.347 & 0.342 & 0.136 & 2.548 & 0.011 & & \\
\hline $\begin{array}{l}\text { Independency (X4) -> Kinerja Non- } \\
\text { Keuangan (Y) }\end{array}$ & 0.352 & 0.359 & 0.157 & 2.233 & 0.026 & & \\
\hline $\begin{array}{l}\text { Responsibility (X3) -> Kinerja Non- } \\
\text { Keuangan (Y) }\end{array}$ & 0.257 & 0.254 & 0.086 & 2.970 & 0.003 & & \\
\hline $\begin{array}{l}\text { Transparancy (X1) -> Kinerja Non- } \\
\text { Keuangan (Y) }\end{array}$ & 0.088 & 0.092 & 0.138 & 0.642 & 0.521 & & \\
\hline Kinerja Non Keuangan (Y) & & & & & & 0.700 & 0.360 \\
\hline
\end{tabular}

Sumber: Olah Data PLS

1. Transparancy tidak berpengaruh signifikan terhadap Kinerja Non-Keuangan karena nilai t statistics sebesar 0,642 dimana lebih kecil dari t tabel = 1,96 dan juga $\mathrm{p}$ values sebesar 0,521 dimana lebih besar dari 0,05. (H1 ditolak)

2. Accountability tidak berpengaruh signifikan terhadap Kinerja Non-Keuangan karena nilai t statistics sebesar 0,109 dimana lebih kecil dari t tabel $=1,96$ dan juga $\mathrm{p}$ values sebesar 0,913 dimana lebih besar dari 0,05. (H2 ditolak)

3. Responsibility berpengaruh positif dan signifikan terhadap Kinerja Non-Keuangan karena nilai t statistics sebesar 2,970 dimana lebih besar dari t tabel $=1,96$ dan juga p values sebesar 0,003 dimana lebih kecil dari 0,05.

(H3 diterima)

4. Independency berpengaruh positif dan signifikan terhadap Kinerja Non-Keuangan karena nilai t statistics sebesar 2,233 dimana lebih besar dari t tabel $=1,96$ dan juga p values sebesar 0,026 dimana lebih kecil dari 0,05.

(H4 diterima)

5. Fairness berpengaruh positif dan signifikan terhadap Kinerja Non-Keuangan karena nilai t statistics sebesar 2,548 dimana lebih besar dari t tabel $=1,96$ dan juga p values sebesar 0,011 dimana lebih kecil dari 0,05. (H5 diterima).

\section{Pembahasan Hasil Penelitian}

\section{Pengaruh Transparancy Terhadap Kinerja Non Keuangan}

Berdasarkan hasil pengujian hipotesis pada tabel 2. bahwa transparency tidak berpengaruh signifikan terhadap Kinerja Non-Keuangan. Hal ini disebabkan kinerja 
non keuangan merupakan kinerja yang dinilai tidak berdasarkan ukuran angka dalam satuan nilai uang, sedangkan transparansi adalah memberikan informasi kepada stakeholders secara terbuka. Pada penelitian ini transparansi tidak berpengaruh terhadap kinerja non keuangan dan transparansi tidak memiliki peranan penting dalam meningkatkan kinerja non keuangan. Menurut teori agensi, sulitnya memonitor atau kurang transparannya proses pengambilan keputusan oleh manajer menyebabkan investor tidak mempunyai informasi yang cukup mengenai kinerja manajer.

Berbagai informasi yang diperoleh kadang berbeda antara satu dengan yang lain dan bahkan bertentangan satu sama lain tentang suatu hal atau masalah, penentuan tentang kebenaran informasi harus dapat dilakukan dengan baik. Hal ini dapat menyebabkan tidak adanya pengetahuan yang menyeluruh terhadap kondisi perusahaan dan tidak akan tercipta lingkungan kerja yang tenang dan kondusif. Karena berbagai keputusan penting bahkan akan berkaitan langsung dengan kelancaran dan kelangsungan pelaksanaan tata kelola perusahaan.

Penelitian ini sejalan dengan penelitian sebelumnya yang menunjukan bahwa transparansi tidak berpengaruh nyata terhadap kinerja non keuangan perusahaan[22], namun tidak sejalan dengan penelitian lainnya yang menunjukan bahwa transparansi berpengaruh positif dan signifikan terhadap kinerja non keuangan perusahaan[21].

\section{Pengaruh Accountability Terhadap Kinerja Non Keuangan}

Berdasarkan hasil pengujian hipotesis pada tabel 2. bahwa accountability tidak berpengaruh signifikan terhadap Kinerja Non-Keuangan. Hal ini disebabkan bahwa prinsip akuntabilitas tidak memiliki peranan penting dalam meningkatkan kinerja non keuangan. Perusahaan gagal dalam menjalankan misi dalam mencapai tujuan dan sasaran yang telah ditetapkan sebelumnya secara periodik. Kinerja perusahaan dikatakan baik apabila setiap perencanaan perusahaan untuk mencapai hasil yang maksimal dari perencanaan tersebut salah satunya pertanggungjawaban pengelolaan yang dilakukan dengan benar untuk mencapai tujuan yang ditetapkan, tetapi pada penelitian ini sebaliknya perusahaan tidak melakukannya dengan benar. Padahal secara teoritis kinerja non keuangan mendapat dukungan penuh dari penerapan prinsip akuntabilitas. Apabila penerapan dan pelaksanaan pertanggungjawaban mengenai sumber-sumber dan penggunaan dana, capaian suatu program, serta kebijakan yang dilaksanakan telah sesuai dengan yang diharapkan, maka kinerja non keuangan akan meningkat.

Penelitian ini sejalan dengan penelitian sebelumnya yang menunjukan bahwa akuntabilitas berpengaruh negatif dan tidak signifikan terhadap kinerja non keuangan perusahaan[21], namun tidak sejalan dengan penelitian lainnya yang menunjukan bahwa akuntabilitas berpengaruh nyata terhadap kinerja non keuangan perusahaan[22].

\section{Pengaruh Responsibility Terhadap Kinerja Non Keuangan}

Berdasarkan hasil uji hipotesis pada tabel 2. bahwa responsibility berpengaruh positif dan signifikan terhadap Kinerja Non-Keuangan. Responsibility diwujudkan 
dengan kesadaran bahwa tanggung jawab merupakan konsekuensi logis dari adanya wewenang, menyadari akan adanya tanggung jawab sosial, menghindari penyalahgunaan kekuasaan. Dengan mematuhi segala peraturan yang ada serta melaksanakan tugas dengan baik, maka dapat memberikan dampak yang baik pula pada kinerja non keuangan perusahaan tersebut. Selain itu, responsibilitas juga mencerminkan kinerja pengelolaan perusahaan yang baik dan mengakui stakeholders serta mendorong kerjasama yang aktif antara perusahaan dengan stakeholders untuk menciptakan kemakmuran. Dan untuk meningkatkan kinerja non keuangan, perusahaan harus memahami dan mematuhi peraturan serta melaksanakan tugas yang telah diberikan terhadap stakeholders sehingga dapat terpelihara kesinambungan usaha dalam jangka panjang. Perusahaan dalam memenuhi tanggung jawab kepada stakeholders harus sesuai dengan hukum dan peraturan perundang-undangan yang berlaku.

Penelitian ini berbeda dengan penelitian yang dilakukan oleh peneliti sebelumnya yang menunjukan responsibility berpengaruh negatif dan tidak signifikan terhadap kinerja non keuangan perusahaan[21], [22].

\section{Pengaruh Independency Terhadap Kinerja Non Keuangan}

Berdasarkan uji hipotesis pada tabel 2. bahwa independency berpengaruh positif dan signifikan terhadap Kinerja Non-Keuangan. Independensi merupakan sikap perusahaan dalam mengambil keputusan tanpa terikat dengan pihak manapun atau pihak yang mendominasi. Hal ini disebabkan bahwa dengan menunjukan tidak adanya benturan kepentingan dalam pengelolaan perusahaan dapat berdampak pada meningkatnya kepercayaan stakeholders serta kinerja non keuangan suatu perusahaan. Prinsip independensi memastikan bahwa perusahaan harus dikelola secara independen dan tidak dapat didominasi dan diintervensi oleh pihak lain agar kekuatan perusahaan seimbang. Selain itu, organ perusahaan harus melaksanakan tugasnya sesuai anggaran dasar dan peraturan serta tidak melempar tanggung jawab.

Penelitian ini sejalan dengan penelitian sebelumnya yaang menyatakan bahwa independency berpengaruh positif dan signifikan terhadap kinerja non keuangan perusahaan[21], namun tidak sejalan dengan penelitian lainnya yang menyatakan bahwa prinsip independency memiliki hubungan yang berlawanan terhadap kinerja non keuangan perusahaan[22].

\section{Pengaruh Fairness Terhadap Kinerja Non Keuangan}

Berdasarkan uji hipotesis pada tabel 2. bahwa fairness berpengaruh positif dan signifikan terhadap Kinerja Non-Keuangan. Hal ini disebabkan apabila pengelolaan perusahaan memperhatikan hak dari stakeholders serta memperlakukannya secara adil berdasarkan asas kewajaran dan kesetaraan maka dapat meningkatkan kinerja non keuangan disuatu perusahaan. Karena fairness merupakan keadilan dan kesetaraan perusahaan dalam memenuhi kepentingan stakeholders yang timbul berdasarkan perjanjian dan peraturan perundang-undangan yang berlaku. Perusahaan harus memperhatikan hak-hak para pemangku kepentingan berdasarkan asas kewajaran dan kesetaraan dalam rangka meningkatkan kinerja non keuangan perusahaan. 
Penelitian ini tidak sejalan dengan penelitian sebelumnya yang mengungkapkan bahwa penerapan prinsip fairness berpengaruh negatif dan signifikan terhadap kinerja non keuangan perusahaan[21].

Penerapan tata kelola perusahaan yang baik (GCG) di Perum Bulog Sub Divre Semarang terus mengalami peningkatan dan penyempurnaan sejalan dengan dinamika penugasan pemerintah dibidang pangan serta komitmen Perum Bulog dalam mewujudkan visi dan misi perusahaan sesuai dengan prinsip-prinsip GCG yaitu terwujudnya SDM professional, jujur dan amanah. Selain itu, dalam rangka meningkatkan kesadaran serta wawasan segenap pegawai dan jajaran Perum Bulog tentang GCG, perusahaan telah melakukan kegiatan sosialisasi pelaksanaan GCG dilingkungan internal perusahaan agar dapat terwujudnya visi dan misi serta kelangsungan usaha dari Perum Bulog Sub Divre Semarang.

\section{Kesimpulan Dan Saran}

\section{Kesimpulan}

Tujuan dari penelitian ini adalah untuk mengidentifikasi pengaruh penerapan tata kelola perusahaan yang baik terhadap kinerja non keuangan pada Perum Bulog Sub Divre Semarang. Dan didapatkan hasil bahwa prinsip transparancy dan accountability tidak berpengaruh signifikan terhadap kinerja non keuangan pada Perum Bulog, penelitian ini sejalan dengan penelitian yang dilakukan oleh beberapa peneliti sebelumnya yang menunjukan bahwa transparancy dan accountability tidak berpengaruh nyata terhadap kinerja non keuangan perusahaan[22], [21], sedangkan prinsip responsibility, independency dan fairness berpengaruh positif dan signifikan terhadap kinerja non keuangan pada Perum Bulog Sub Divre Semarang, penelitian ini sejalan dengan penelitian sebelumnya yang mendapatkan hasil positif dan signifikan terhadap kinerja non keuangan[21].

Beberapa keterbatasan dalam penelitian ini adalah jumlah responden yang hanya 40 orang, yang mengakibatkan kurangnya informasi untuk menggambarkan keadaan yang sesungguhnya. Dalam proses pengambilan data, informasi yang diberikan responden melalui kuesioner terkadang tidak menunjukan pendapat responden yang sebenarnya, hal ini terjadi karena perbedaan pemikiran, anggapan dan pemahaman yang berbeda tiap responden.

\section{Saran}

Saran yang dapat disampaikan untuk penelitian selanjutnya sebaiknya penelitian selanjutnya disarankan untuk mengambil sampel yang lebih banyak dan dapat dilakukan pada seluruh jajaran struktural perusahaan, hal ini bertujuan untuk keakuratan data yang lebih baik dalam penelitian, penelitian dapat ditambahkan variabel independen lainnya seperti variabel kepuasan kerja dan prestasi kerja yang berkemungkinan besar dapat mempengaruhi kinerja.

\section{Ucapan Terima Kasih}

Terima kasih penulis ucapkan kepada semua pihak yang telah membantu dan mendukung penelitian ini yaitu Perum Bulog Sub Divre Semarang, sehingga 
penelitian ini dapat berjalan dengan baik dan dapat memberikan hasil yang bermanfaat bagi pengguna.

\section{Referensi}

[1] A. A. A. P. Mangkunegara, Manajemen Sumber daya Manusia Perusahaan. Bandung: PT Remaja Rosdakarya, 2005.

[2] G. Dessler, Manajemen Sumber Daya Manusia, 14th ed. Salemba Empat, 2015.

[3] A. A. N. Supit, J. J. Tinangon, and H. Sabijono, "Analisis Kinerja Non Keuangan PT. Otsuka Indonesia Cabang Mando,” J. EMBA, vol. 2, no. 2, pp. 1607-1616, 2014.

[4] W. Maulana and C. L. Surya, "Penilaian Kinerja PT. Bank Jatim Cabang Pamekasan dengan Penerapan Metode Balanced Scorecard," J. Manag. Account., vol. 2, no. 1, pp. 57-71, 2019.

[5] F. Rangkuti, SWOT Balanced Scorecard: Teknik Menyusun Strategi Korporat yang Efektif plus Cara Mengelola Kinerja dan Risiko, 1st ed. Jakarta: Gramedia Pustaka Utama, 2014.

[6] R. S. Kaplan and D. P. Norton, Balanced Scorecard: Menerapkan Strategi Menjadi Aksi, 1st ed. Jakarta: Erlangga, 2000.

[7] E. Lubis and H. Susanto, "Penerapan Good Corporate Governance Di Pasar Modal Sebagai Upaya Melindungi Investor," J. Huk. dan Bisnis, vol. 5, no. 1, pp. 48-76, 2019, doi: 10.35814/selisik.v5i1.1285.

[8] M. Nasution and D. Setiawan, "Pengaruh Corporate Governance Terhadap Manajemen Laba Di Industri Perbankan Indonesia," Simp. Nas. Akunt. X, no. Juli, pp. 1-26, 2007, [Online]. Available: http://www.starwoodhotels.com/corporate/about/investor/governance.html.

[9] I. W. Sukardika and I. W. G. W. P. Anggara, "The Effect of Application of Good Corporate Governance Principles on the Performance of Rural Credit Banks in Badung Regency," E-Jurnal Akunt., vol. 30, no. 8, pp. 2025-2039, 2020.

[10] T. Y. Sari, "Pengaruh penerapan prinsip," Univ. Muhammadiyah Palembang, 2017.

[11] J. I. Febriani, M. Al Musadieq, and T. W. Afrianty, "Pengaruh Good Corporate Governance Terhadap Kinerja (Studi Pada Karyawan PT Pos Indonesia (Persero) Tuban)," J. Adm. Bisnis, vol. 32, no. 1, pp. 82-89, 2016.

[12] I. Widodo, "Analisis Kinerja Perusahaan dengan Menggunakan Pendekatan Balanced Scorecard (Studi Kasus pada Perusahaan Mebel PT. Jansen Indonesia)," Manajemen, vol. 1-1, no. ff, pp. 1-34, 2011.

[13] D. P. Hapsari, "Analisis Implementasi Penerapan Prinsip - Prinsip Goo Dcorporate Governance Dan Pengaruhnya Terhadap Kinerja Perusahaan," J. TEKUN, vol. VIII, no. 01 , pp. 64-79, 2017.

[14] D. Fitriyani, W. Tiswiyanti, and E. Prasetyo, "Good Corporate Governance dan 
Dampaknya Terhadap Kinerja Berdasarkan Balanced Scorecard," J. Akunt., vol. 20, no. 3, pp. 420-447, 2016, [Online]. Available: http://www.petra.ac.id/ puslit/journals/dir.php?DepartmentID=MAN.

[15] P. P. A. Nugraheni, "Penerapan Corporate Governance Dengan Menggunakan Balance Scorecard Pada Bank Mandiri Jember," Bisma, vol. 11, no. 3, pp. 378-389, 2018, doi: 10.19184/bisma.v11i3.6478.

[16] B. Mattson, "Executives learn how to keep score: Balanced Scorecard gets all employees focusing on vision," 1999.

[17] Y. Sudaryo and R. Andari, "Pengaruh Penerapan Good Corporate Governance Terhadap Kinerja Perusahaan dengan Pendekatan Balance Scorecard pada PT Telekomunikasi Indonesia Tbk," J. Indones. Membangun, vol. 16, no. 2, pp. 177190, 2017.

[18] N. L. P. A. Pratiwi and I. G. A. M. A. D. Putri, "Pengaruh Good Corporate Governance Pada Kinerja Berbasis Balanced Scorecard," E-Jurnal Akunt. Univ. Udayana, vol. 15, no. 2, p. hal. 832-846, 2016, [Online]. Available: https://ojs.unud.ac.id/index.php/Akuntansi/article/view/11137.

[19] Y. Puspitha and Sujana, "Budaya Organisasi Pemoderasi Pengaruh Prinsip Good Corporate Governance Pada Kinerja Perusahaan Berbasis Balanced Scorecard," EJurnal Akunt. Univ. Udayana, vol. 14, no. 3, pp. 1978-2012, 2016.

[20] I. M. Kesuma and Y. Nurhayati, "Pengaruh Penerapan Good Corporate Governance Dalam Meningkatkan Kinerja Rumah Sakit di Kota Lubuklinggau dan Kabupaten Musi Rawas Dengan Pendekatan Balanced Scorecard," J. Ecoment Glob., vol. 5, no. 1, pp. 12-27, 2020, doi: 10.35908/jeg.v5i1.804.

[21] S. D. Puspa and Y. Yulinda, "Pengaruh Penerapan Prinsip Good Corporate Governance Terhadap Kinerja Non-Keuangan Pada Perusahaan B'Right Pln Batam," J. Appl. Manag. Account., vol. 3, no. 1, pp. 66-80, 2019, doi: 10.30871/jama.v3i1.962.

[22] I. S. Irwondy and M. Hubeis, "Pengaruh Penerapan Konsep Good Corporate Governance Terhadap Kinerja Non-Keuangan di Kantor Pusat PT Asuransi Jasa Indonesia," J. Manaj. dan Organ., vol. 7, no. 2, pp. 98-110, 2017, doi: 10.29244/jmo.v7i2.16567.

[23] bulog.co.id, 2020.

[24] Sugiyono, Metode Penelitian Bisnis. Bandung: Alfabeta, 2008. 